JOURNAL OF SECURITY AND SUSTAINABILITY ISSUES ISSN 2029-7017 print/ISSN 2029-7025 online

2020 March Volume 9 Number 3

https://doi.org/10.9770/jssi.2020.9.3(2)

\title{
Scopus
}

\section{TOWARDS ENVIRONMENTAL SUSTAINABILITY: A CASE STUDY OF GREEN SUPPLY CHAIN MANAGEMENT PRACTICE}

\author{
Chaithanaskorn Phawitpiriyakliti ${ }^{1 *}$, Boonthai Keawkunti ${ }^{2}$, Chompoo Saisama $^{3}$, Watcharin Sangma ${ }^{4}$ \\ ${ }^{1,2,3,4}$ College of Innovation Management, Suan Sunandha Rajabhat University, Bangkok, Thailand \\ E-mails: ${ }^{1}$ chaithanaskorn.ph@ssru.ac.th (Correspondingauthor); ${ }^{2}$ boonthai.ke@ssru.ac.th; \\ ${ }^{3}$ chompoo.sa@ssru.ac.th; ${ }^{4}$ watcharin.sa@ssru.ac.th
}

Received 10 February 2019; accepted 18 December 2020; published 30 March 2020

\begin{abstract}
The main objective of the study is to investigate the moderating effect of green Supply Chain Management Practices (GSCMP), Internail Environment Management (IEM), Internal Supply Chain Process (ISCP), Quality Information System (QIS), Green Knowledge Management Capability (GKMC), and Environment Performance (EP) of pharmaceutical industry of Thailand. For this purpose, data has been collected from the 500-supply chain and procurement managers which yield a $68 \%$ response rate. The SEM analysis has shown that ISCM has a positive and significant association with the EP, GKMC also has positive and significant association with the EP. In the same vein, it is also found that IEM and QIS have a positive and significant association with the EM of pharmaceutical industry of Thailand. On the other hand, indirect moderating also shows GSCMP has a significant moderation on the relation of ISCP, IEM, QIS and EP of pharmaceutical industry of Thailand. Whereas, GSCM did not significantly moderates on the relationship of GKMC and EP. These findings show that GSCMP is considered to be a significant moderator because it has moderating effect in most of exogenous and endogenous variable. Thus, based on this study contributed a body of knowledge in the form of empirical findings which could become a new area of research in future. The current study could provide some guidelines to supply chain and procurement department to know about the importance GSCMP to increase the EM. The research limitations and future directions are also discussed at the end of the study.
\end{abstract}

Keywords: green supply chain management practices; internal environment management; internal supply chain process; green knowledge management capability; environment performance, pharmaceutical, Thailand

Reference to this paper should be made as follows: Phawitpiriyakliti, C., Keawkunti, B., Saisama, C., Sangma, W. 2020. Towards environmental sustainability: a case study of green supply chain management practice. Journal of Security and Sustainability Issues, 9(3), 747-763. https://doi.org/10.9770/jssi.2020.9.3(2)

JEL Classification: O53

\section{Introduction}

Wide arrow of environmental sustainability facets is in focus both of society and researchers in recent years (e.g. Sarma, Karnitis, Zuters, \& Karnitis, 2019; Moumen, El Idrissi, Tvaronavičienė, \& Lahrach, 2019. Fatoki, 2019; Lavrinenko, Ignatjeva, Ohotina, Rybalkin, \& Lazdans, 2019).

Integration of sustainability concerns in the supply chain management practices has appeared to be a topic of interest among researchers (Chetthamrongchai \& Jermsittiparsert, 2019; Jermsittiparsert, Namdej, \& Sriyakul, 2019; Somjai \& Jermsittiparsert, 2019). Public awareness is increasing and in presence of strict regulations regarding the environment and sustainability, green supply chain management practices have appeared to be a vital factor in the Thai organizations (Jermsittiparsert, Siriattakul, \& Sangperm, 2019). The concern for the environment in the developed countries it is obvious from the strict regulations such as "WEEE and ROHS directives". Thus, it made it impossible for the businesses to ignore their supply chain impact on the environ- 
ment (Jermsittiparsert et al., 2019). Pharmaceutical manufacturers' supply chain is directly influenced by the environmental guidelines especially in emerging countries. Firms have employed certain green practices in their supply chains, and they are striving hard for its improvement.

Therefore, it makes it important to study how the firms' knowledge and environmental capabilities contributes in the sustainable supply chains and finally its influence on the environment. Employees employed across pharmaceutical industry is subsectors in Thailand (Kritchanchai, 2012). Organizations are working on environmental concerns due to their processes and in this regard, they have addressed the certain issues and adopting the environment friendly supply chain philosophy. Whereas at the other end, organizations are also striving hard to get their supply chain integration into business process which results in minimum cost and provide the customers with optimal services while also dealing with pressure to survive in competitive pressure (Ali \& Haseeb, 2019). Competing in competitive environment and taking care of the environment calls for the attention towards the strategies which can make the supply chain strategies better and contribute towards the better environmental performance. Organizations compete on their resources and knowledge is one of the core resources organizations do have (Muhammad, Qazi Muhammad Adnan, \& Aviral Kumar, 2013). It is regarded as the strategic resource which helps an organization to survive, being stable, grow and improve. Azapagic (2015) also further suggested that it is serves the basis to boost the performance of an organization. Further, it can also make sure the smooth sharing of information and support among employees which further translates into efficiency and creativity. Knowledge management helps an organization to develop approaches which do assist the acquisition of right knowledge at right time. Chan, He, Chan, and Wang (2012) further recommended that it is one of the main facets of an organization and also knowledge management is regarded as an important capabilities of firms which could make to an organization successful because these are regarded as asset which assists the integration between all supply chain partners. Moreover, Attia (2016) made an argument that scarce studies are available on the association between knowledge management and supply chain practices. Empirical evidence is present, which states that the green practices in supply chains assist an organization to outperform in fiscal and environmental performance. In this regard, Dubey, Gunasekaran, and Ali (2015) suggested that it is much needed to pinpoint the drivers require to employee the green supply chain management practices. Further it was also argued that even though these practices have gained much attention in recent two decades, still there is need to study the construct to get more insights in future studies (Kritchanchai, Somboonwiwat, \& Chanpuypetch, 2015; Nakornsri \& Lee, 2008). In addition, previous studies also have a main focus on the developed economies, whereas, there is a little attention on the developing economies especially on the pharmaceutical industry of Thailand. As, this industry in Thailand has a big contribution in the social and economic development, therefore, the industry could not be ignored.

As, customer awareness regarding the environment has increase as compared to previous decade, firms' practices embed its image in mind of customers. So, to manage the sustained competent Thai Pharmaceutical industry it has become essential to create a good image of organizations. The main objective of the study is to investigate the moderating effect of green Supply chain management practices (GSCMP), Internal Environment Management (IEM) internal supply chain process (ISCP), quality information system (QIS), green knowledge management capability (GKMC), and environment performance (EP) of pharmaceutical industry of Thailand. Later sections of the study mention literature review, methods, results and potential areas for future studies.

\section{Literature Review}

Generally speaking, how do the firm's actions impact the environment can be regarded as the environmental performance (EP) of that firm. The environmental performance can be positive or negative based on its impact on environment. Therefore, Rotova (2018) suggested that the EP denotes to the impact of activities of an organization on the environment. In order to get the better EP, it is necessary for an organization to point out the sources for the environmental problems such as logistics, procurement and production etc. From supply chain management practices (SCMP) perspective (Darroch, 2005; Nonaka \& Takeuchi, 1995; Sohal, Ragsdell, Hislop, \& Brown, 2018) explained that EP measures the organizations' ability to lessen the emission of CO2, 
$\mathrm{SO} 2$, NOx and other dangerous gases which results due to overall activities in a supply chain of an organization. It can be stated as a relationship between the firm and the environment which contains the outcomes of usage of resources, impact of organizational activities, goods and services on environment and meeting the legal requirements. According to Green, Inman, Sower, and Zelbst (2019) during the production process businesses often use bundle of resources which are already limited. Thus, they result in environmental problems by releasing the waste into water, air and cause the pollution. Green et al. (2019) further explored that actually EP assesses the capability of an organization to lessen the waste, pollution, prevention of hazardous chemicals and reduce its impact on the environment. Similarly, it was argued that the rising environmental concerns have made it necessary for the organizations to reconsider their impact on environment and address the concerns regarding the environmental performance (Yildiz Çankaya \& Sezen, 2019).

\section{Green supply chain management practices}

The rising environmental issues such as global warming, resource depletion, change in biodiversity has put the sustainability at danger. Individuals from diverse areas such as professionals, scientists, academicians and scholars are working to recommend the possible ways to keep the environmental sustainability (Wilairatana, Ngamjarussrivichai, Takuma, \& Konosu, 2018). In this regard it is explained that the unexpected and reckless industrial actions carry a possible danger to the sustainability. Which has resulted in an attempt to develop sustainable practices in every industry. It can be termed as "Green practices". The word green implies that performing the actions by considering their impact on environment and ecology (Wilairatana et al., 2018). Therefore, the environmental concerns have triggered the move to redesign the supply chain to be sustainable (Jermsittiparsert et al., 2019). Being a significant component of operations management, supply chain has viable impact on the environment in form of emissions, pollutions etc. Jermsittiparsert et al. (2019) also explained that environment related concerns have become part of the organizations as an effort to lessen their environmental impression. Furthermore, Jermsittiparsert et al. (2019) suggested that the application of green concept (environment related concerns) in SCMP is termed as green supply chain management practices (GSCMP). In addition, Attia and Salama (2018) also defined the GSCMPs as "integrating environmental thinking into supply-chain management, including product design, material sourcing and selection, manufacturing process, delivery of end-of-life management of the product after its useful life".

Further, Fernando, Walters, Ismail, Seo, and Kaimasu (2018) also proposed GSCMP as "an integration of concerns regarding the environment into the internal practices of an organization which are linked with the sustainable supply chain". GSCMP have been defined by different researchers differently. For instance, Wilairatana et al. (2018) also recommended that "it is the broad concept and there is no single clear definition to define it". Regardless of definitions and different conceptualizations GSCMP are focused on the following aspects: environmental issues should be kept in mind while designing a product, what is the impact of organization on the environment, green procurement, production, distribution and also the green reverse logistics. It also focuses on the five practices such as reduction of waste, remanufacturing, recycling, and alternatives disposal which is primarily focused to reduce the waste generation inside the supply chain (Hou, Hsieh, \& Lin, 2019; Yang \& Yang, 2019). It also improves the operational performance of business and environmental performance of an organization (Yang \& Yang, 2019).

\section{Internal supply chain process and Environment performance}

Internal supply chain process (ISCP) also recognized as rearrangement is referred to the application of go forward along with one and more than functions like production, sourcing, and convey to a considerable subsequently point in SCM (Ahmad, Bin Mohammad, \& Nordin, 2019; Johnson \& Davis, 1998; Van Hoek, Vos, \& Commandeur, 1999). An author revealed that there is a necessary to develop rearrangement strategy like examining how more steps a company wants to delay and which step they will be postpone (Varsei \& Polyakovskiy, 2017; Verma, 2014). Benefit of postponement for firm is that firm have extra time for making changes in needs of customers and moderation of the demand function (Waller et al., 2000). ISCP have being a positive impact on EP (Wijetunge, 2017). Based on the previous discussion, the following hypotheses is proposed for the current study: 
H1: There is a significant association between the Internal supply chain process and Environment performance of Pharmaceutical industry of Thailand.

\section{Green knowledge management capability and environment Performance}

Recent, decade has seen an increasing research trend on how the knowledge management contributes towards the supply chain management (SCM). Considerable research has concluded that the knowledge management results in improved SCM (Yang \& Yang, 2019). Further Green et al. (2019) also discussed that the knowledge management capability of the organizations helps them to improve their performance. Organizations through their knowledge management capabilities can exploit the new knowledge, gain the new knowledge which will contribute towards the competitiveness of organization. It is the organizational capability which addresses the firm's ability to gain, create, and transfer, integration, sharing and application of resources regarding the knowledge and activities across the functional boundaries to produce new knowledge. Further the implementation of knowledge management in organizations provide them with the ability to cope with the ever-rising competition in the corporate world. Some researchers have regarded the knowledge management capability as set of knowledge process and include some aspects such as knowledge attainment, distribution and employment (Layachi, 2019; Myambo \& Munyanyi, 2017), documenting, acquiring (Arfi, Hikkerova, \& Sahut, 2018; Hassan \& AlHakim, 2011) and documenting the knowledge, transfer and protect it . Based on the above conceptualizations and different perceptions of the researchers it is argued that "the green knowledge management capability denotes the firm's ability to gain, create, and transfer, integration, sharing and application of resources regarding the knowledge and activities across the functional boundaries to produce new knowledge related to go green concept" (Albort-Morant, Leal-Rodríguez, \& De Marchi, 2018; Arfi et al., 2018). Which is ultimately aimed for the betterment of the organizations' performance in an environment.

Al-Ghwayeen and Abdallah (2018) further conducted a study by collection of responses from the companies they reported that KMC of an organization significantly impact the supply chain management practices. Previously it is argued that when knowledge is shared, integrated and applied between the supply chain members it leads towards the significant benefits for an organization which include the cost and cycle time reduction, improved quality and good customer services (Petljak, Zulauf, Štulec, Seuring, \& Wagner, 2018). Therefore, the knowledge management between the supply chain members led towards the productive processes involved in supply chain (Jermsittiparsert et al., 2019). It ultimately increases the chances to survive in competitive environment. Similarly, conducted a study by Papa, Dezi, Gregori, Mueller, and Miglietta (2018) which conclude that supply chain knowledge management capabilities are dynamic capabilities which lead towards the productive decision making. Which ultimately improves the supply chain performance. There is insufficient empirical evidence available regarding the link between knowledge management capabilities and supply chain management practices (Gilal, Zhang, Gilal, \& Gilal, 2018). Based on the previously mentioned literature review it is hypothesized that:

H2: There is significant relationship between the Green knowledge management capability and environment of pharmaceutical industry of Thailand.

\section{Internal environment management and Environment performance}

According to Feng et al. (2018) and Darnall, Jolley, and Handfield (2008) explained that internal environmental management refers to the firms' policies to safeguard the environment and targets to ensure the environment safety. All the policies and targets are made by organizations. Internal environment management practices make sure the support from all managerial managers regarding the practices related to environment management. It also makes sure the cooperation between the different departments regarding the environmental improvements and building a system (Malimi, 2017)Profitability, and Loan Growth on Non-Performing Loans a Case of Tanzanian Banking Sector $</$ title $><$ secondary-title $>$ International Journal of Economics, Business and Management Studies $</$ secondary-title $></$ titles $><$ periodical $><$ full-title $>$ International Journal of Economics, Business and Management Studies $<$ /full-title $><$ /periodical $><$ pages $>38-49<$ pages $><$ volume $>4</$ volume $><$ number $>1<1$ 
number $><$ dates $><$ year $>2017</$ year $><$ dates $><$ urls $><$ urls $></$ record $></$ Cite $></$ EndNote $>$. All the practices mentioned earlier falls under broad domain of internal environment management. Similar term such as green internal management has also been used to conceptualize this construct which denotes the practices of an organization which are employed with the primary aim to lessen the impact of an organization on the environment. These practices include the policies, internal awareness and regulatory compliance of an organization with the environment (Soner, Gul, \& Yildirim, 2016).

GSCMP ask for greater coordination such as for developing a new product aligned with green concept requires collaboration with customers for the integration of their demands while product is in design process. Internal extensive environmental management ask for great deal of coordination. This can be attributed to the internal environment management (Foerstl, Azadegan, Leppelt, \& Hartmann, 2015; Schmidt, Foerstl, \& Schaltenbrand, 2017). TQM and JIT are the factors of internal environment. In this regard, Dubey et al. (2015) concluded that JIT and TQM both are significantly related with the GSCMP and both of them advances the green practices of an organization. Based on the literature it is hypothesized that:

H3: There is significant association between the Internal environment management and environment of the pharmaceutical industry of Thailand.

\section{Quality of information sharing and environment performance}

Quality of information sharing (QIS) contain timeliness, accuracy, credibility, adequacy, as final credibility of the information communicated (Moberg et al., 2002; Monczka et al., 1998). Furthermore, information sharing is historical, and significant of its effect on supply chain management (SCM) with that what, when, and with all information shared (Holmberg, 2000; Khalil, Khalil, \& Khan, 2019). Consequently, business need to interpret their significant information as firm asset and confirm that information should be communicated with the minimum delay and distortion ( $\mathrm{Li}$ et al., 2006). Empirically, a positive effect of the QIS on FP has been found in the study of (Li et al., 2006). For the current studies there are following hypotheses are proposed:

H4: There is significant association between the quality of information sharing and environment of the pharmaceutical industry of Thailand.

\section{GSCMP as a moderator among the exogenous and endogenous variable}

An organization's performance in environment can be significantly improved by green supply chain management practices as it is focused to eradicate all kinds of environmental wastes. These practices also do decrease the ecological impact as these are focused for better environmental performance by decreasing the emissions and release of solid wastes in water (Dubey et al., 2015). Similarly, other study by Rotova (2018) conducted a study and collected data from the companies dealing in chemicals, automotive and electronics companies (Ali \& Haseeb, 2019). The results reported a significant and positive connection between internal environment management and GSCMP. Regarding the green practices, it is argued that these lead towards the improved environmental performance by decreasing the wastes resulted due to the businesses. Conclusively the environment is positively influence by green supply chain practices. So, it is hypothesized that:

Previously various studies have reported a significant and positive link between the knowledge management capability and GSCMP (Dalpati, Rangnekar, \& Birasnav, 2010; Desouza, Chattaraj, \& Kraft, 2003; Green Jr, Zelbst, Meacham, \& Bhadauria, 2012; Loke, Downe, Sambasivan, \& Khalid, 2012). Which asserts that when the organization is successfully acquiring, sharing and implementing the knowledge related to green practices throughout the supply chain then it leads towards the green supply chain management practices. Similarly, when firms also do maintain their internal environmental it will also lead towards the green supply chain management performance. Which finally will improve the environmental performance of a firm. It has been supported by previous study which argued that manufacturing firms which do follow the JIT and TQM improves their green supply chain performance as JIT are focused to reduce the waste and TQM are focused at to provide 
with optimal quality products and services. Thus, it ends up in improved environmental performance (Dubey et al., 2015). Green supply chain management practices are broad in context and are inclusive of every effort which is aimed to reduce the organizational adverse effect on the environment (Rotova, 2018). Based on the previously available empirical evidence it is hypothesized that:

H5: Green supply chain practices are significantly moderating between Internal supply chain process and environment performance of pharmaceutical industry of Thailand.

H6: Green supply chain practices are significantly moderating between green knowledge management capability and environment performance of pharmaceutical industry of Thailand.

H7: Green supply chain management practices are significantly moderating between internal environmental management and environment performance of pharmaceutical industry of Thailand.

H8: Green supply chain management practices are significantly moderating between quality of information system and environment performance of pharmaceutical industry of Thailand.

Research Conceptual Framework (see figure 1)

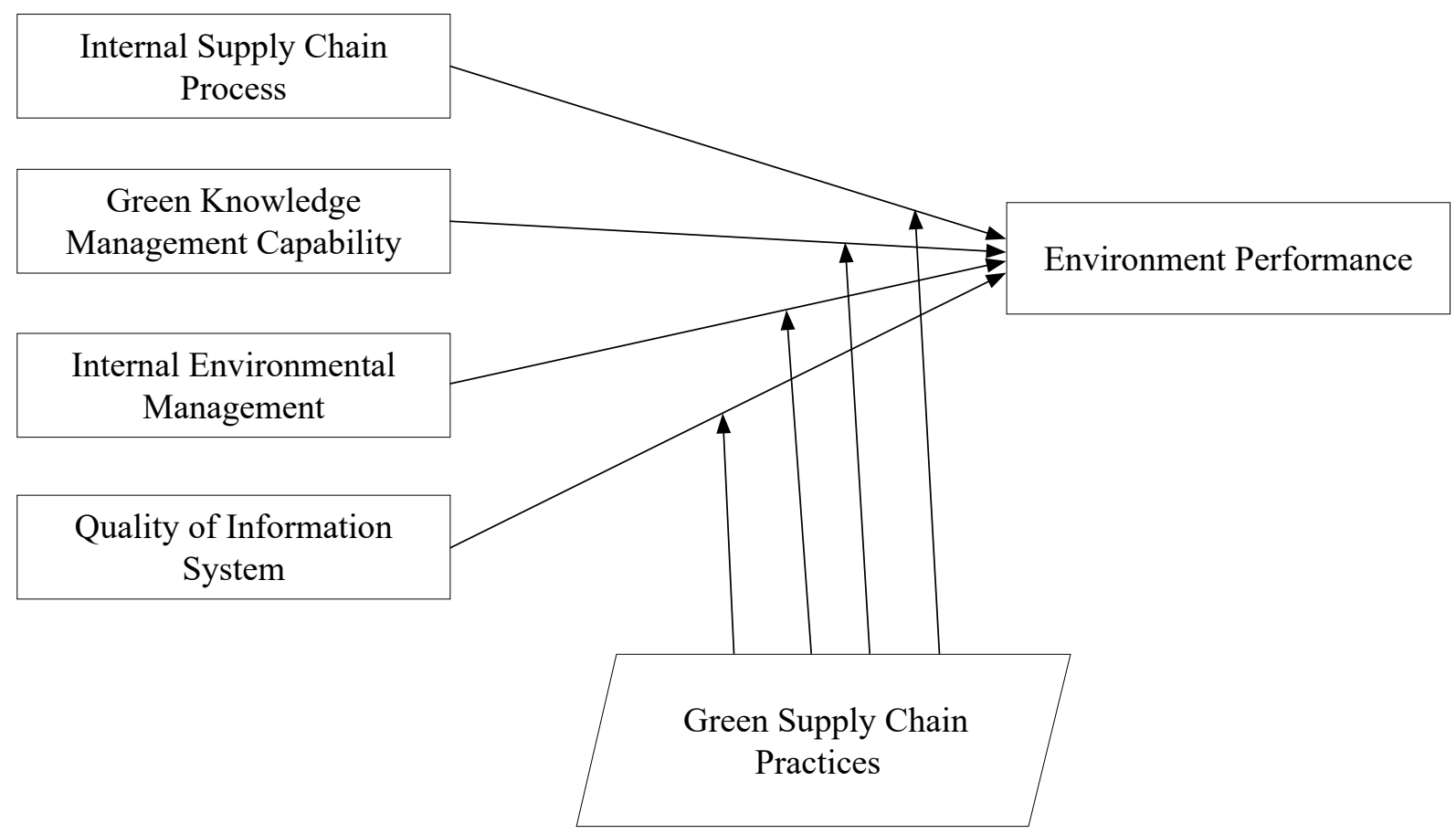

Figure 1. Research Framework of the study

\section{Research Methodology}

The current study used cross sectional research design and quantitative research approach. In the current study, the model and hypothesis were tested in manufacturing industry of Thailand. The manufacturing sector of Thailand has been recognized as $2^{\text {nd }}$ largest producer, which makes it an important sector to study. For the data collection, the 500 questionnaires were distributed among the supply chain and procurement mangers of the pharmaceutical industry of Thailand by using the purposive sampling technique. Among of the 500 questionnaires 340 questions were returned back which yield a $68 \%$ response rate. As, questionnaire was used for data collect and it was consisted of two sections which are as follows: First section consisted upon the demographic 
information of the respondents. The second section consisted upon the questions regarding the variables under study. Following are the details of the measures adapted for the present study. To measure the green knowledge management capability of the organization 15 items scale was adapted (Dalpati et al., 2010; Ibrahim, Mukhtar, \& Gani, 2017; Jermsittiparsert et al., 2019). Internal environmental management was measured by using 7 items scale, green supply chain management practices were measured by using 16 items scale and 6 items scale was used to measure the Environmental performance (Jermsittiparsert et al., 2019; Suy, Chhay, \& Choun, 2018). In addition, for the quality of information system 4 items were adopted from the study of (Li, RaguNathan, Ragu-Nathan, \& Rao, 2006). Lastly, for the internal supply chain process three items was adopted from the study of Li et al. (2006).

\section{Analysis and Discussions}

The SEM-PLS, which in modern times is one of the robust techniques to analyses the data on social issues is used as the statistical tool in currents study. Recently many researchers such as Patidar and Din (2018) and Ahmed, Zin, and Majid (2016) has employed and argued that whenever we are dealing with some novelty in conceptual models or need an advance assessment of any existing phenomena, we prefer SEM-PLS over other technique such as multiple regression analysis. Patidar and Din (2018) and Ahmad et al. (2019) and Henseler, Ringle, and Sinkovics (2009) further argued that the PLS-SEM is a two-step equation, which is an advance form of multiple regression and accounts for two assessments namely the inner model assessment and the outer model assessment. The first step is estimation of the reliability and validity of the model. In Smart- PLS, after obtaining the results of reliability and validity for each construct, examining the structural model results is necessary in order to test the hypothesis. There are five steps of procedures in examining the structural model results; (1) examine the structural model for collinearity issues; (2) the significance of path coefficients; (3) followed by examining the level of $\mathrm{R}^{2}$ values; (4) assessment of $\mathrm{f} 2 \mathrm{effect}$ size; and last but not least, (5) examining the predictive relevance $\left(\mathrm{Q}^{2}\right)$ (Hair, Hollingsworth, Randolph, \& Chong, 2017a; Henseler et al., 2009). The reason why the SEM-PLS is preferred the multiple regression is that the earlier handles the multiple equations simultaneously and can produces results with a simultaneous operation by producing a relationship with all direct and intervening phenomena. Reliability analysis is performed in order to find internal consistency of the items. Cronbach's alpha is the most widely used in order to test the reliability level. Although there are many findings that founds that the value of composite reliability is always higher than Cronbach's alpha.

An indicator declared as valid and significant if it has a loading factor over than 0.5 on the targeted construct (Hair et al., 2017a). Thus, this study analyzed the output of the loading factors which gained thru Smart-PLS. Before testing the hypothesis, data reliability and validity was scrutinized. These steps were taken through PLS 3. The factor loading of all the items in the current study are greater than 0.5 and Cronbach's alpha value is greater than 0.70 . Moreover, for the convergent validity average variance extracted (AVE) should be greater than 0.5 (Hair, Hollingsworth, Randolph, \& Chong, 2017). All of the values are greater than 0.5. In additon, to measure the distriminant validity, cross loading, Fornell Lacker and HTMT are the three critereas. In the discriminant validitiy, the value of Fornel Lacker diagnol values should be greater than from other values. In additon, the minminmum values for the HTMT should be less than 0.90 (Henseler, Ringle, \& Sarstedt, 2015). All of the values for the convergent and discriminant values are depicted in the Table 1,2 and 3.

Table 1. Confirmatory Factor Analysis

\begin{tabular}{|c|c|c|c|c|c|}
\hline Constructs & Items & Loadings & Alpha & CR & AVE \\
\hline Environmental Performance & EP1 & 0.785 & 0.776 & 0.85 & 0.554 \\
\hline & EP2 & 0.827 & & & \\
\hline & EP3 & 0.840 & & & \\
\hline $\begin{array}{c}\text { Green Knowledge Management } \\
\text { Capability }\end{array}$ & EP4 & 0.829 & & & \\
\hline
\end{tabular}




\begin{tabular}{|c|c|c|c|c|c|}
\hline & GKMC2 & 0.433 & & & \\
\hline & GKMC3 & 0.504 & & & \\
\hline & GKMC4 & 0.736 & & & \\
\hline & GKMC5 & 0.703 & & & \\
\hline & GKMC6 & 0.687 & & & \\
\hline & GKMC7 & 0.757 & & & \\
\hline & GKMC8 & 0.717 & & & \\
\hline & GKMC9 & 0.683 & & & \\
\hline & GKMC10 & 0.648 & & & \\
\hline & GKMC11 & 0.402 & & & \\
\hline & GKMC12 & 0.530 & & & \\
\hline & GKMC13 & 0.682 & & & \\
\hline & GKMC14 & 0.474 & & & \\
\hline & GKMC15 & 0.438 & & & \\
\hline \multirow[t]{15}{*}{$\begin{array}{c}\text { Green Supply Chain } \\
\text { Management Practices }\end{array}$} & GSCMP1 & 0.692 & 0.903 & 0.915 & 0.524 \\
\hline & GSCMP2 & 0.717 & & & \\
\hline & GSCMP3 & 0.589 & & & \\
\hline & GSCMP4 & 0.718 & & & \\
\hline & GSCMP5 & 0.764 & & & \\
\hline & GSCMP6 & 0.759 & & & \\
\hline & GSCMP7 & 0.728 & & & \\
\hline & GSCMP8 & 0.705 & & & \\
\hline & GSCMP9 & 0.715 & & & \\
\hline & GSCMP10 & 0.694 & & & \\
\hline & GSCMP11 & 0.698 & & & \\
\hline & GSCMP12 & 0.465 & & & \\
\hline & GSCMP13 & 0.462 & & & \\
\hline & GSCMP14 & 0.455 & & & \\
\hline & GSCMP15 & 0.462 & & & \\
\hline \multirow[t]{7}{*}{ Internal Environment Management } & IEM1 & 0.791 & 0.845 & 0.884 & 0.526 \\
\hline & IEM2 & 0.807 & & & \\
\hline & IEM3 & 0.723 & & & \\
\hline & IEM4 & 0.463 & & & \\
\hline & IEM5 & 0.748 & & & \\
\hline & IEM6 & 0.782 & & & \\
\hline & IEM7 & 0.704 & & & \\
\hline \multirow[t]{3}{*}{ Internal Supply Chain process } & ISCP1 & 0.617 & 0.76 & 0.821 & 0.53 \\
\hline & ISCP 2 & 0.784 & & & \\
\hline & ISCP 3 & 0.757 & & & \\
\hline \multirow[t]{4}{*}{ Quality of information sharing } & QIS1 & 0.764 & 0.77 & 0.833 & 0.50 \\
\hline & QIS2 & 0.754 & & & \\
\hline & QIS3 & 0.685 & & & \\
\hline & QIS4 & 0.748 & & & \\
\hline
\end{tabular}

Note: is presenting the values for 'factor loadings', 'composite reliability (CR)' and 'average variance extract (AVE)'. If factors loadings are greater than 0.50 it adds to the convergent validity of measurement. Table 1 and figure 2 is showing that all the factor loadings are in acceptable range. For convergent validity the values for CR and AVE should be greater than 0.8 and 0.5 respectively and all the values for CR and AVE are within acceptable range which established the convergent validity. 
Table 2. Forner Lacker Discriminant Validity

\begin{tabular}{ccccccc}
\hline & EP & GKMC & GSCMP & IEM & ISCP & QIS \\
\hline EP & $\mathbf{0 . 8 7 0}$ & & & & & \\
GKMC & 0.334 & $\mathbf{0 . 7 5 0}$ & & & & \\
GSCMP & 0.168 & 0.500 & $\mathbf{0 . 8 7 9}$ & & & \\
IEM & 0.449 & 0.340 & 0.600 & $\mathbf{0 . 7 8 0}$ & & \\
ISCP & 0.719 & 0.607 & 0.724 & 0.611 & $\mathbf{0 . 8 6 0}$ & \\
QIS & 0.230 & 0.260 & 0.490 & 0.230 & 0.340 & $\mathbf{0 . 7 8 9}$ \\
\hline
\end{tabular}

Note: EP-Environmental Performance, GKMC- Green Knowledge Management Capability, GSCM- Green Supply Chain Management Practices, IEM- Internal Environment Management, ISCP- Internal Supply Chain process, QIS-quality information system.

Table 3. HTMT Discriminant

\begin{tabular}{ccccccc}
\hline & EP & EP & EP & EP & EP & EP \\
\hline EP & & & & & & \\
GKMC & 0.334 & & & & & \\
GSCMP & 0.168 & 0.724 & 0.560 & & & \\
IEM & 0.449 & 0.823 & 0.600 & 0.611 & & \\
ISCP & 0.719 & 0.607 & 0.490 & 0.230 & 0.340 & \\
QIS & 0.230 & 0.260 & 0.490 &
\end{tabular}

Note: EP-Environmental Performance, GKMC- Green Knowledge Management Capability, GSCM- Green Supply Chain Management Practices, IEM- Internal Environment Management, ISCP- Internal Supply Chain process, QIS-quality information system.

\section{Structural Model}

\section{Direct Effect}

The next steps in assessing the structural model are to examine the hypothesized relationships among constructs in the measurement model. The model explanatory power was resolute through inspecting how well the observed data fit the hypothesized relationship among the constructs. Following, Chin (1998), bootstrap the resampling approach has been hired to test all the significant of all each coefficient. As recommended by Hair et al. (2014), five thousand duplications through using the randomly selected subsamples which were performed to test all the hypothesized relationships. Table 4 depicts the beta coefficients and t-values for the first 4 direct hypotheses.

The SEM analysis has shown that internal supply chain management (ISCM) has a positive and significant association with the environment performance (EP). Similarly, green knowledge management capability (GKMC) also shown the positive and significant association with the EP. In the same vein, internal environmental management (IEM) also shown the positive and significant association with the EP. Likewise, quality of information sharing (QIS) also shown the positive and significant association with the EP. All of the four direct hypotheses of the study are supported. These findings indicate that pharmaceutical companies of Thailand have a greater emphasis on supply chain activities to enhance their environmental performance. All of the results are depicted in the following Table 4. 
Table 4. Direct Effect of the Model

\begin{tabular}{cccccc}
\hline & Beta & SD & T Statistics & P Values & Results \\
\hline ISCP-> EM & 0.104 & 0.052 & 2.002 & 0.046 & Supported \\
GKMC EM & 0.548 & 0.057 & 9.626 & 0.000 & Supported \\
IEM -> EM & 0.355 & 0.1 & 3.554 & 0.000 & Supported \\
QIS-> EM & 0.693 & 0.044 & 15.736 & 0.000 & Supported \\
\hline
\end{tabular}

Note: EP-Environmental Performance, GKMC- Green Knowledge Management Capability, GSCM- Green Supply Chain Management Practices, IEM- Internal Environment Management, ISCP- Internal Supply Chain process, QIS-quality information system, $\mathrm{p}<0.05$

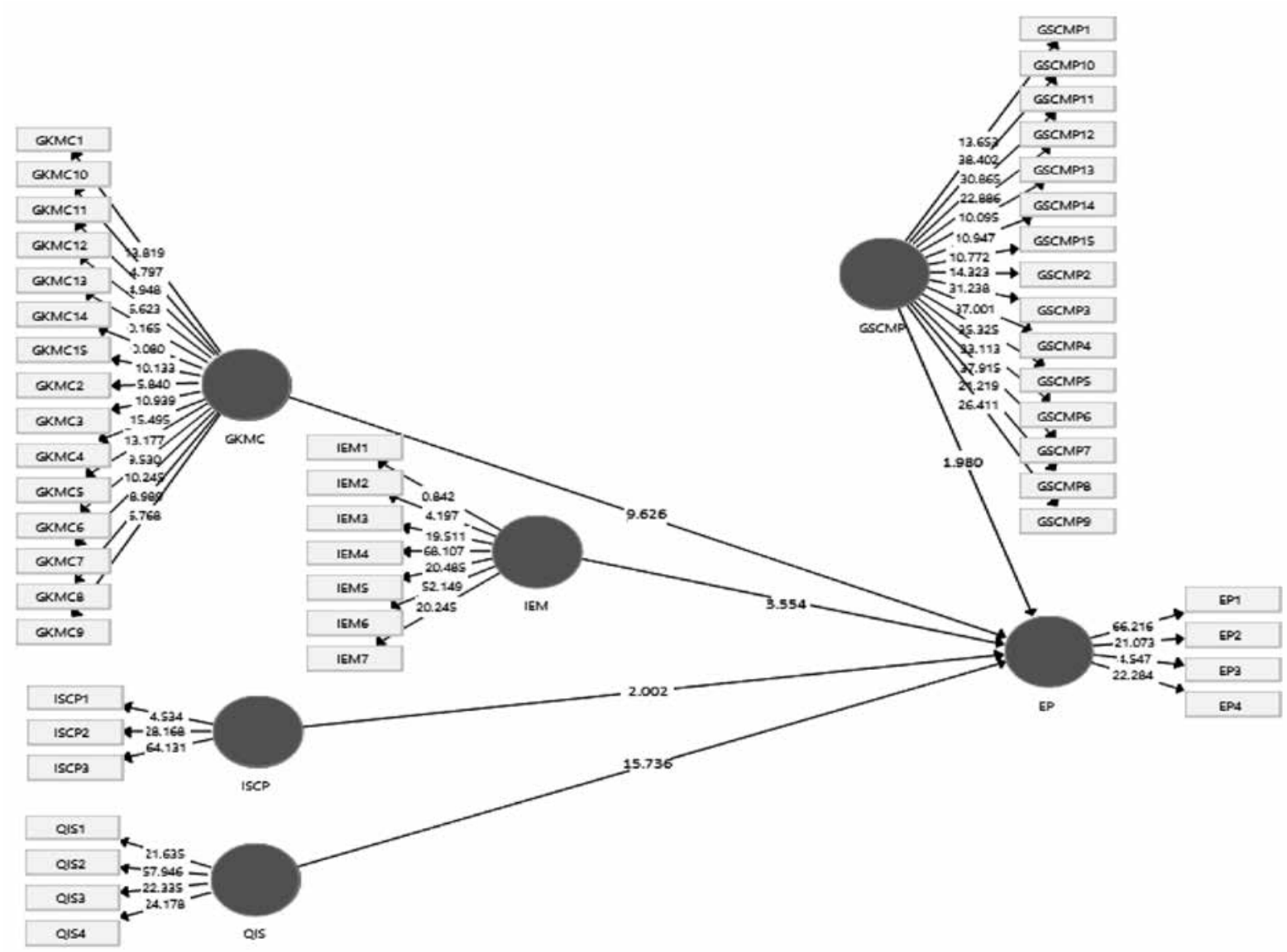

Figure 2. Direct effect of structural model

\section{Indirect Effect}

The research model hypothesized that green supply chain management practices (GSCMP) moderate in the relationship of three antecedents of exogenous and endogenous variable. The moderation test in the current study was to be employed through using the two-stage calculation approach. This approach was employed as per the suggestion of the Hair, Hult, Ringle, and Sarstedt (2017b), who suggested that when the study objective is whether is that moderating variable significantly moderates in the relationship of exogenous and endogenous variable. For this purpose, to test the moderation hypotheses, this study has used (Baron \& Kenny, 1986) criteria to determine whether the moderation condition is exist.

The indirect effect of SEM analysis has shown that GSCMP is significantly moderates in the relationship of ISCP and EM and hypothesis (5) is supported, whereas, GSCMP has insignificant moderating effect in the rela- 
tionship of GKMC and EM and hypothesis (6) is not supported. On the other hand, it found that GSCMP is significantly and positively moderates in the relationship of IEM and EM and hence, hypothesis (7) is supported. In addition, GSCM also significantly moderates in the relationship of QIS and EM, therefore hypothesis (8) is supported. These findings show pharmaceutical companies of Thailand has greater emphasis on the GSCMP to enhance the SCM practices for the improvement of EP. The GSCMP is not significantly moderates on the relationship of GSCMP and EP. One of the possible reasons for this relationship is due to overlapping of other variables. All of the results are depicted in the following Table 5.

Table 5. Indirect effect of the structural model

\begin{tabular}{|c|c|c|c|c|c|c|}
\hline & Beta & SD & T Statistics & P Values & Beta & Results \\
\hline ISCP* GSCMP -> EM & 0.196 & 0.207 & 0.067 & 2.906 & 0.004 & supported \\
\hline GKMC* GSCMP->EM & -0.059 & -0.064 & 0.05 & 1.17 & 0.242 & Not supported \\
\hline IEM* GSCMP -> EM & 0.48 & 0.484 & 0.078 & 6.16 & 0.000 & supported \\
\hline QIS* GSCMP -> EM & 0.941 & 0.941 & 0.006 & 14.926 & 0.000 & supported \\
\hline
\end{tabular}

Note: EP-Environmental Performance, GKMC- Green Knowledge Management Capability, GSCM- Green Supply Chain Management Practices, IEM- Internal Environment Management, ISCP- Internal Supply Chain process, QIS-quality information system, $\mathrm{p}<0.05$

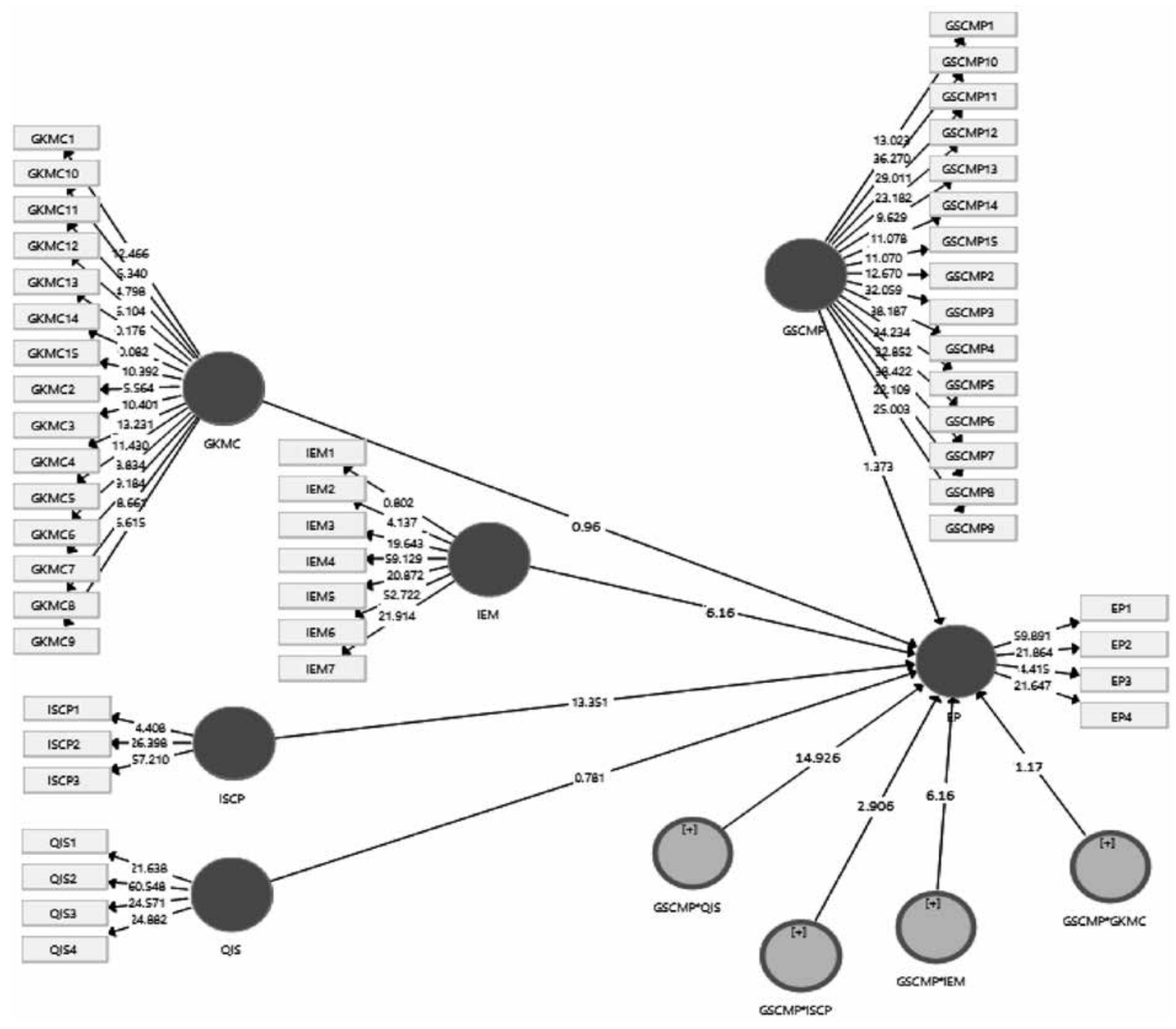

Figure 1. Indirect effect 


\section{Conclusion}

The main objective of the study is to investigate the moderating effect of green Supply chain management practices (GSCM), Internal Environment Management (IEM) internal supply chain process (ISCP), quality information system (QIS), green knowledge management capability (GKMC), and environment performance (EP) of pharmaceutical industry of Thailand. To achieve this objective, following hypothesis was formulated. The key findings of the study reported that direct effect of the study has shown that all the exogenous variables have a significant and positive association with the EP of the pharmaceutical industry of Thailand. In addition, indirect effect of the study also shows that GSCMP has a significant moderating effect in most of the exogenous variables and EP of pharmaceutical industry of Thailand. These findings show that GSCMP is considered to be significant moderating in the exogenous and EP of pharmaceutical industry of Thailand. The key findings also show that GSCMP is significantly moderates on the relationship of GKMC and EP. One of the possible reasons for this relationship is that there is overlapping of other variable between this relationship. On the other hand, one of the other reasons is might be a that respondents are given the importance of GSCMP for this relationship.

This study offers some valuable managerial implications for the managers in the pharmaceutical industry regarding how they can maintain and improve the green supply chain management practices and improve their overall environmental performance. This study has reported the role of managing knowledge to improve the supply chain and environmental performance. Furthermore, the managers will be able to utilize the findings for the more deeply integration of green concept in the supply chain. It will also help the managers to reduce their organizations' impact on the environment. While the study has successfully accomplished its objectives though there are some limitations as well which must be taken under consideration while results interpretation. Firstly, this study only considered the pharmaceutical industry, so it serves as an opportunity for the future studies to segregate the study sample regarding their nature of business such as trading, manufacturing and supporting accessories of the electronics industry. It will provide a comparative view regarding the perceptions of managers/owners in the same industry with different nature of business regarding the green supply chain management practices. Further it is suggested that the data should be collected from more respondents (like employees) in similar industry or other industry. Moreover, collection of data from different supply chain partners will provide more valuable insights regarding the green supply chain management practices. In addition, the study was consisting of cross-sectional research design, therefore a future research could be established that should be longitudinal in nature.

\section{References}

Ahmad, R., Bin Mohammad, H., \& Nordin, S. B. (2019). Moderating effect of board characteristics in the relationship of structural capital and business performance: An evidence on Pakistan textile sector. Journal of Studies in Social Sciences and Humanities, 5(3), 89-99.

Ahmed, U., Zin, M. L. M., \& Majid, A. H. A. (2016). Impact of Intention and Technology Awareness on Transport Industry's E-service: Evidence from an Emerging Economy. 산경연구논집 (IJIDB), 7(3), 13-18. https://doi.org/10.13106/ijidb.2016.vol7.no3.13

Albort-Morant, G., Leal-Rodríguez, A. L., \& De Marchi, V. (2018). Absorptive capacity and relationship learning mechanisms as complementary drivers of green innovation performance. Journal of Knowledge Management, 22(2), 432-452. https://doi.org/10.1108/ JKM-07-2017-0310

Al-Ghwayeen, W. S., \& Abdallah, A. B. (2018). Green supply chain management and export performance: The mediating role of environmental performance. Journal of Manufacturing Technology Management, 29(7), 1233-1252. https://doi.org/10.1108/JMTM-032018-0079

Ali, A., \& Haseeb, M. (2019). Radio frequency identification (RFID) technology as a strategic tool towards higher performance of supply chain operations in textile and apparel industry of Malaysia. Uncertain Supply Chain Management, 7(2), 215-226. http://dx.doi. $\operatorname{org} / 10.5267 /$ j.uscm.2018.10.004

Arfi, W. B., Hikkerova, L., \& Sahut, J.-M. (2018). External knowledge sources, green innovation and performance. Technological Forecasting and Social Change, 129, 210-220. https://doi.org/10.1016/j.techfore.2017.09.017

Attia, A. M. (2016). The effect of triple-A supply chain on performance applied to the Egyptian textile industry. International Journal of Integrated Supply Management, 10(3/4), 225-245. https://dx.doi.org/10.1504/IJISM.2016.081264 
Attia, A., \& Salama, I. (2018). Knowledge management capability and supply chain management practices in the Saudi food industry. Business Process Management Journal, 24(2), 459-477. https://doi.org/10.1108/BPMJ-01-2017-0001

Azapagic, A. (2015). Systems approach to corporate sustainability: a general management framework. Process Safety and Environmental Protection, 81(5), 303-316. https://doi.org/10.1205/095758203770224342

Baron, R. M., \& Kenny, D. A. (1986). The moderator-mediator variable distinction in social psychological research: Conceptual, strategic, and statistical considerations. Journal of Personality and Social Psychology, 51(6), 1173-1182. https://doi.org/10.1037//00223514.51.6.1173

Chan, R. Y., He, H., Chan, H. K., \& Wang, W. Y. (2012). Environmental orientation and corporate performance: The mediation mechanism of green supply chain management and moderating effect of competitive intensity. Industrial Marketing Management, 41(4), 621-630. https://doi.org/10.1016/j.indmarman.2012.04.009

Chetthamrongchai, P. \& Jermsittiparsert, K. (2019). The Mediating Role of Supply Chain Management Practices in the Relationship between Manufacturing Flexibility and Manufacturing Performance. Humanities and Social Sciences Reviews, 7(3), 736-743. https:// doi.org/10.18510/hssr.2019.73104

Dalpati, A., Rangnekar, S., \& Birasnav, M. (2010). Knowledge management and supply chain flexibility performance in Indian manufacturing industry: an empirical study. Global Journal of E-business and Knowledge Management, 6(1), 10-16.

Darnall, N., Jolley, G. J., \& Handfield, R. (2008). Environmental management systems and green supply chain management: complements for sustainability? Business strategy and the Environment, 17(1), 30-45. https://doi.org/10.1002/bse.557

Darroch, J. (2005). Knowledge management, innovation and firm performance. Journal of Knowledge Management, 9(3), 101-115. https://doi.org/10.1108/13673270510602809

Desouza, K. C., Chattaraj, A., \& Kraft, G. (2003). Supply chain perspectives to knowledge management: research propositions. Journal of Knowledge Management, 7(3), 129-138. https://doi.org/10.1108/13673270310485695

Dubey, R., Gunasekaran, A., \& Ali, S. S. (2015). Exploring the relationship between leadership, operational practices, institutional pressures and environmental performance: A framework for green supply chain. International Journal of Production Economics, 160, 120-132. https://doi.org/10.1016/j.ijpe.2014.10.001

Fatoki, O. (2019). Green entrepreneurial orientation and firm performance in South Africa, Entrepreneurship and Sustainability Issues, 7(1), 247-262. http://doi.org/10.9770/jesi.2019.7.1(19)

Feng, M., Yu, W., Wang, X., Wong, C. Y., Xu, M., \& Xiao, Z. (2018). Green supply chain management and financial performance: The mediating roles of operational and environmental performance. Business strategy and the Environment, 27(7), 811-824. https://doi. org/10.1002/bse.2033

Fernando, Y., Walters, T., Ismail, M. N., Seo, Y. W., \& Kaimasu, M. (2018). Managing project success using project risk and green supply chain management: A survey of automotive industry. International Journal of Managing Projects in Business, 11(2), 332-365. https:// doi.org/10.1108/IJMPB-01-2017-0007

Foerstl, K., Azadegan, A., Leppelt, T., \& Hartmann, E. (2015). Drivers of supplier sustainability: Moving beyond compliance to commitment. Journal of supply chain management, 51(1), 67-92. https://doi.org/10.1111/jscm.12067

Gilal, F. G., Zhang, J., Gilal, N. G., \& Gilal, R. G. (2018). Integrating self-determined needs into the relationship among product design, willingness-to-pay a premium, and word-of-mouth: a cross-cultural gender-specific study. Psychology research and behavior management, 11, 227. https://doi.org/10.2147/PRBM.S161269

Green Jr, K. W., Zelbst, P. J., Meacham, J., \& Bhadauria, V. S. (2012). Green supply chain management practices: impact on performance. Supply Chain Management: An International Journal, 17(3), 290-305. https://doi.org/10.1108/13598541211227126

Green, K. W., Inman, R. A., Sower, V. E., \& Zelbst, P. J. (2019). Impact of JIT, TQM and green supply chain practices on environmental sustainability. Journal of Manufacturing Technology Management, 30(1), 26-47. https://doi.org/10.1108/JMTM-01-2018-0015

Hair, Hollingsworth, C. L., Randolph, A. B., \& Chong, A. Y. L. (2017a). An updated and expanded assessment of PLS-SEM in information systems research. Industrial Management \& Data Systems, 117(3), 442-458. https://doi.org/10.1108/IMDS-04-2016-0130

Hair, J. F., Hult, G. T. M., Ringle, C., \& Sarstedt, M. (2017b). A primer on partial least squares structural equation modeling (PLS-SEM): Sage publications.

Hassan, S., \& Al-Hakim, L. A. Y. (2011). The relationships among critical success factors of knowledge management, innovation and 
organizational performance: A conceptual framework.

Henseler, J., Ringle, C. M., \& Sarstedt, M. (2015). A new criterion for assessing discriminant validity in variance-based structural equation modeling. Journal of the academy of marketing science, 43(1), 115-135. https://doi.org/10.1007/s11747-014-0403-8

Henseler, J., Ringle, C. M., \& Sinkovics, R. R. (2009). The use of partial least squares path modeling in international marketing. In New challenges to international marketing (pp. 277-319): Emerald Group Publishing Limited. https://doi.org/10.1108/S14747979(2009)0000020014

Holmberg, S. (2000). A systems perspective on supply chain measurements. International Journal of Physical Distribution \& Logistics Management, 30(10), 847-868. https://doi.org/10.1108/09600030010351246

Hou, Y.-Y., Hsieh, H.-Y., \& Lin, M.-H. (2019). A Study on the Effect of Applying Information Technology to Environmental Management on Firm Competitiveness. Ekoloji Dergisi (107).

Ibrahim, S. S., Mukhtar, S., \& Gani, I. M. (2017). Relationship between Electricity Consumption, Manufacturing Output and Financial Development: A New Evidence from Nigeria. Energy Economics Letters, 4(3), 28-35.

Jermsittiparsert, K., Namdej, P., \& Sriyakul, T. (2019). Impact of Quality Management Techniques and System Effectiveness on the Green Supply Chain Management Practices. International Journal of Supply Chain Management, 8(3), 120-130.

Jermsittiparsert, K., Siriattakul, P., \& Sangperm, N. (2019). Predictors of Environmental Performance: Mediating Role of Green Supply Chain Management Practices. International Journal of Supply Chain Management, 8(3), 877-888.

Johnson, M. E., \& Davis, T. (1998). Improuing supply chain performance by using order fulfillment metrics. National Productivity Review, 17(3), 3-16. https://doi.org/10.1002/npr.4040170304

Khalil, M., Khalil, R., \& Khan, S. (2019). A study on the effect of supply chain management practices on organizational performance with the mediating role of innovation in SMEs. Uncertain Supply Chain Management, 7(2), 179-190. http://dx.doi.org/10.5267/j. uscm.2018.10.007

Kritchanchai, D. (2012). A Framework for Healthcare Supply Chain Improvement in Thailand Improvement in Thailand. Operations and supply chain management, 5(2), 103-113. http://dx.doi.org/10.31387/oscm0120080

Kritchanchai, D., Somboonwiwat, T., \& Chanpuypetch, W. (2015). Supply chain of Thailand product champion: a case study of the passenger car tyre industry. International Journal of Logistics Systems and Management, 20(1), 83-102. https://doi.org/10.1504/ IJLSM.2015.065966

Lavrinenko, O., Ignatjeva, S., Ohotina, A., Rybalkin, O., Lazdans, D. (2019). The Role of Green Economy in Sustainable Development (Case Study: The EU States), Entrepreneurship and Sustainability Issues, 6(3), 1013-1026. http://doi.org/10.9770/jesi.2019.6.3(4)

Layachi, O. B. (2019). Effects of Energy Prices on Environmental Pollution: Testing Environmental Kuznets Curve for Algeria. International Journal of Energy Economics and Policy, 9(5), 401. https://doi.org/10.32479/ijeep.8312

Li, S., Ragu-Nathan, B., Ragu-Nathan, T., \& Rao, S. S. (2006). The impact of supply chain management practices on competitive advantage and organizational performance. Omega, 34(2), 107-124. https://doi.org/10.1016/j.omega.2004.08.002

Loke, S.-P., Downe, A. G., Sambasivan, M., \& Khalid, K. (2012). A structural approach to integrating total quality management and knowledge management with supply chain learning. Journal of Business Economics and Management, 13(4), 776-800. https://doi.org/ $10.3846 / 16111699.2011 .620170$

Malimi, K. (2017). The Influence of Capital Adequacy, Profitability, and Loan Growth on Non-Performing Loans a Case of Tanzanian Banking Sector. International Journal of Economics, Business and Management Studies, 4(1), 38-49. https://doi.org/10.20448/802.41.38.49

Moumen, Z., El Idrissi, N.E.A., Tvaronavičienė, M., Lahrach, A. (2019). Water security and sustainable development. Insights into Regional Development, 1(4), 301-317. https://doi.org/10.9770/ird.2019.1.4(2)

Muhammad, S., Qazi Muhammad Adnan, H., \& Aviral Kumar, T. (2013). Economic Growth, Energy Consumption, Financial Development, International Trade and CO2 Emissions, in Indonesia. https://doi.org/10.1016/j.rser.2013.04.009

Myambo, A., \& Munyanyi, T. (2017). Effecetiveness of Labour Court in Labour Dispute Management in Zimbabwe. International Journal of Social and Administrative Sciences, 2(1), 15-30. https://doi.org/10.18488/journal.136.2017.21.15.30

Nakornsri, T., \& Lee, S. M. (2008). Strategic Characteristics of Supply Chain Management among Thai Manufacturers. Retrieved by May, 1, 2013. 
Nonaka, I., \& Takeuchi, H. (1995). The knowledge-creating company: How Japanese companies create the dynamics of innovation: Oxford university press.

Papa, A., Dezi, L., Gregori, G. L., Mueller, J., \& Miglietta, N. (2018). Improving innovation performance through knowledge acquisition: the moderating role of employee retention and human resource management practices. Journal of Knowledge Management. https:// doi.org/10.1108/JKM-09-2017-0391

Patidar, R., \& Din, T. M. U. (2018). A Study on the Fluctuating Trend of Export (Demand Change) of 'Garlic of India'by its Price Transformation in International Markets, Under the Time Period of 1991 to 2011. International Journal of Applied Economics, Finance and Accounting, 2(2), 54-59. https://doi.org/10.33094/8.2017.2018.22.54.59

Petljak, K., Zulauf, K., Štulec, I., Seuring, S., \& Wagner, R. (2018). Green supply chain management in food retailing: survey-based evidence in Croatia. Supply Chain Management: An International Journal, 23(1), 1-15. https://doi.org/10.1108/SCM-04-2017-0133

Rotova, N. A. (2018). Development of Independence among Future Primary School Teachers by Applying Interactive Learning Methods. Journal of Education and e-Learning Research, 5(2), 118-121.

Sarma, U., Karnitis, G. Zuters, J.; Karnitis, E. 2019. District heating networks: enhancement of the efficiency, Insights into Regional Development, 1(3), 200-213. https://doi.org/10.9770/ird.2019.1.3(2)

Schmidt, C. G., Foerstl, K., \& Schaltenbrand, B. (2017). The supply chain position paradox: green practices and firm performance. Journal of supply chain management, 53(1), 3-25. https://doi.org/10.1111/jscm.12113

Sohal, D., Ragsdell, G., Hislop, D., \& Brown, P. (2018). Sustainable knowledge management: The role of knowledge management audits.

Somjai, S. \& Jermsittiparsert, K. (2019). Role of Pressures and Green Supply Chain Management Practices in Enhancing the Operational Efficiency of Firms: Evidence from Thailand. International Journal of Supply Chain Management, 8(4), 437-445.

Soner, A., Gul, Z., \& Yildirim, U. (2016). A Theoretical Analysis upon the Environmental Health and Justice Issue: A Case Study for a Comparison Between G20s Unitary and Federal Members. International Journal of Sustainable Development \& World Policy, 5(2), 26-38. https://doi.org/10.18488/journal.26/2016.5.2/26.2.26.38

Suy, R., Chhay, L., \& Choun, C. (2018). Protection and Management Policy on Angkor Wat Temple in Cambodia: An Overview. Asian Themes in Social Sciences Research, 1(1), 10-13.

Van Hoek, R. I., Vos, B., \& Commandeur, H. R. (1999). Restructuring European supply chains by implementing postponement strategies. Long Range Planning, 32(5), 505-518. https://doi.org/10.1016/S0024-6301(99)00071-0

Varsei, M., \& Polyakovskiy, S. (2017). Sustainable supply chain network design: A case of the wine industry in Australia. Omega, 66, 236-247. https://doi.org/10.1016/j.omega.2015.11.009

Verma, A. S. (2014). Sustainable supply chain management practices: Selective case studies from Indian hospitality industry. International Management Review, 10(2), 13-23.

Wilairatana, P., Ngamjarussrivichai, P., Takuma, H., \& Konosu, T. (2018). Study on the Current Situation of User Interface Design in the Thai Manufacturing Industry. Paper presented at the Proceedings of International Association of P2M 2018 Spring.

Yang, C.-Y., \& Yang, C.-H. (2019). The Impact of Sustainable Environmental Management in the Food and Beverage Industry on Customer Loyalty: A View of Brand Attitude. Ekoloji Dergisi (107).

Yildiz Çankaya, S., \& Sezen, B. (2019). Effects of green supply chain management practices on sustainability performance. Journal of Manufacturing Technology Management, 30(1), 98-121. https://doi.org/10.1108/JMTM-03-2018-0099 
Chaithanaskorn PHAWITPIRIYAKLITI is an Assistant Professor of Professional Football Management Program, College of Innovation Management, Suan Sunandha Rajabhat University, Thailand. His research areas are Innovation Management, Digital Marketing, and Sport Management.

Boonthai KEAWKUNTI is a Lecturer of Innovative Management Program, College of Innovation Management, Suan Sunandha Rajabhat University, Thailand. His research areas are Business Administration, Innovation Management, and Leadership.

Chompoo SAISAMA is a Lecturer of e-Sport Management Program, College of Innovation Management, Suan Sunandha Rajabhat University, Thailand. Her research areas are Innovation Management, e-Sport Management and Marketing.

Watcharin SANGMA is a Lecturer of Innovative Management Program, College of Innovation Management, Suan Sunandha Rajabhat University, Thailand. His research areas are Innovation Management, Industrial Management, and Materials Handling Technology.

Register for an ORCID ID:

https://orcid.org/register 